DOI https://doi.org/10.18551/rjoas.2016-12.01

\title{
GREEN MANAGEMENT BY MULTINATIONAL COMPANIES IN DEVELOPING COUNTRIES: ENVIROPRENEUR STRATEGY OR STRATAGEM?
}

\author{
Riduan \\ Management Department, STIE Muhammadiyah Kalianda, Indonesia \\ E-mail: riduanmob@yahoo.com
}

\begin{abstract}
Green management concept has recently become persistent and frequently discussed public issue as the effect of dramatic increase in environmental awareness all over the world. Consumers start to understand that careful selection of products can help protecting the environment while enviropreneurs start to consider effects of their business activities to the environment. However, how environmentally-friendly is a green environment? Is it business strategy or stratagem? The study answered sceptism related to the implementation of green marketing in Multinational Companies in developing countries. The data obtained from from 75 consumers of the products manufactured by Nestle in Lampung, Indonesia were analyzed using path analysis method. The findings showed green management had significant influence towards consumer preference but conventional marketing mix the company applied did not have significant influence towards the consumer preference. Some recommendations were formulated as the response towards the findings.
\end{abstract}

\section{KEY WORDS}

Green marketing, enviropreneur, mnc, developing countries, Indonesia.

Since the late 1980s until the last few decades, consumer awareness towards the environment has increased progressively as more evidence that consumerism contributes to environmental degradation such as pollution, deforestation, climate change and global warming begin to appear. Protecting the environment becomes a need and inseparable part of urbanism agenda. Recently, more consumers believe that environmental issue is a pivotal issue to discuss. They are willing to purchase more expensive, environmental-friendly products (Saini, 2013; Chhay et al, 2015; Biswas, 2016).

The phenomenon encourages green consumerism movement indicated by consumer awareness towards their rights to get feasible, safe, environmental-friendly products. Green consumers are the result of public concern towards the environment so that the public decide to buy green products.

Companies realize that they can take advantage of the momentum of green consumerism by managing the environment issues more carefully and gaining more profit from that. The companies are inspired to put the environment issues as their priorities as one of their marketing strategies well-known as green marketing.

Green marketing concept has been acknowledged widely by the scientific community and defined in various perspectives globally. Green management can be defined by effort of an organization to define, promote, set price and distribute products that do not cause any damage to the environment (Fuller, 1999).

Even though green marketing is more frequently applied in the developed Western countries (Karna et al, 2003 di Eropa, Ogunmakun et al, 2012 di Australia; Rivera-Camimo, 2007 di Spanyol;), developing countries in Asia (Chan and Lau, 2000 in China; Tantawi et al, 2009 in Egypt; Siddique et al, 2013 in Pakistan; Chhay et al, 2015 di Cambodia; Hassan and Ali, 2015 in Malaysia) begin to catch-up. Green management practice and green consumerism movement has expanded to Asia where environmental damage has begun to be threats for both the government and the society.

In Indonesia, green marketing has yet been implemented effectively in general. Specifically, large companies especially multinational companies has started to pay serious attention to green marketing. However, in domestic scale, few companies use green 
marketing as strategy to achieve competitive advantage. Furthermore, Barthel and Ivanaj (2007) stated that long-term orientation and sustainable management are not the only elements to ensure successful green business. Green business also requires marketing strategy to promote the business.

Nestlé Indonesia is the subsidiary of Nestlé S.A., a multinational company (MNC) the headquarter of which is located in Vevey, Switzerland. The company is considered as best practice in the implementation of green marketing. Three factories of Nestlé Indonesia-one of which is located in Pabrik Panjang, Lampung, Indonesia-were awarded Penghargaan Industri Hijau 2013 and Penghargaan Industri Hijau 2014 (Green Industry Awards) by the Ministry of National Industry as their effort to use raw materials, water and energy effectively and sustainably as well as apply environmental friendly principles in their production, and at the same time create benefit for the society (Nestle Indonesia, 2014).

Nestlé believes that in order to become a successful company, the community as well as the society surrounding the company should be prosperous. In the long-term, healthy society, sustainable environment, healty economics and healthy company will influence each other. Nestle has applied green technology to produce its food and beverages products for example baby food, milk, coffee, and chocolate. As an addition, Nestle is committed to maintain sustainable water and environment as well as build the rural areas (Nestle Indonesia, 2013).

Green marketing is predicted as a potential and strategic opportunity that has multiplier effect for either business people (Hassan and Ali, 2015), consumer (Boztepe, 2012) and the public (Singh and Khan, 2014). However, on the other side, sceptism and public and government distrust towards the implementation of green marketing start to appear (Marques and Almeida, 2013). Instead of considering green marketing as their strategy (Das et al, 2012; Hassan and Ali, 2015: Morrone et al, 2015), companies may consider it as stratagem or trick (Brown, 1996) that results in green consumer impulsive buying.

Uniquely, green marketing in Indonesia has yet been implemented thoroughly at each function of strategic marketing. Green marketing in Indonesia tends to emphasize on developing green products; companies have yet been able to develop other functions for example green price, green channel of distribution and green promotion extensively. Therefore, there is preliminary hypothesis that green marketing may not result in Indonesian consumers purchasing environmental-friendly or green products; instead, the phenomenon may occur due to the conventional marketing mix. Which one that has stronger impact for consumer preference? Does green marketing influence the consumer preference? Does the conventional marketing mix alone result in such consumer preference?

The study carries important originality. Studies related to the implementation of green marketing by MNC in foreign countries have been conducted previously such as ones conducted by Barthel and Ivanaj (2007) and Yilmazsoy et al (2015). Similar studies have also been conducted in Indonesia for instance ones conducted by Khoirudin et al, (2016) and Silvia et al (2014). However, studies about green marketing of which setting in MNCs in Indonesia analyzing and comparing green marketing and conventional marketing mix performance towards consumer preference is limited in number; the issue is rarely explored so that it is expected that the study provides its own insight.

Futhermore, the study aims at evaluating and analyzing the implementation of green marketing by one of the brances of Nestle Indonesia located in Pabrik Panjang, Lampung in the perspective of Nestle consumers in Lampung. The study tests the influence and benchmark the implementation of green marketing and conventional marketing mix towards consumer preference.

\section{LITERATURE REVIEW}

Green Purchase Behavior. Lee (2009) translated green purchase as actions to consume environmental-friendly products and awareness towards environmental issues. The term green purchase behavior is similar to green buying (Kim and Choi 2005), pro- 
environment buying (Tilikidou, 2007) and environmentally responsible buying (Follows and Jobber, 2000)

Furthermore, green consumption behavior is different from consumer purchasing behavior in general. In general purchasing behavior, individual consumers decide benefit and cost of a productct before purchasing. On the other hand, green buying does not focus solely on individual consumption, but it also emphasizes on continuous result in the future that has positive contribution to both individuals and the public as well as the environment in general (Mc Carty and Shrum, 2001; Kim and Choi, 2005).

Enviropreneur. Enviropreneur or also known as ecopreneur, according to Isaak (1998), is an individual that develops environmental-friendly business. Enviropreneur goes after social and environmental benefit through increasing company profit. Dean and McMullen (2007) define enviropreneur as entrepreneur who combine environmental awareness and business activities in order to shift the foundation of economic development into more environmental-friendly one. Initially, Vraradarajan (1992) introduced enviropreneurial marketing as environmentally-friendly marketing practice, strategy and tactics started by marketing companies (1) to achieve competitive advantage among their competitors, and (2) influenced by perspective of companies related to their tasks and responsibility towards the public and the environment.

Green marketing. Green marketing refers to holistic management process that identifies and anticipates fulfillment of consumer and public need through beneficial and sustainable method (Peattie and Crane, 2005). Green marketing is not a non-profit charity. As a matter of fact, green marketing is expected to bring benefit not only for the company but also for the environment and society.

Besides that, Ottman (1992) explained that green marketing refers to marketing nonpoisonous, durable and degradable products. Pride and Ferrell (1993) proposed wider definition of green marketing that is effort of an organization to design products, decide price, promote, and distribute products that do not cause damage to the environment.

Green Products. Green product is essential for natural resource conservation and sustainable development. Companies can use the green product to minimize cost or gain profit due to their concern to the environment. In this case, companies may decrease pollutant that may cut some huge expenses. Gnanapandithan and Rajasekaran (n.d.) define green products as ones that fulfill one or all of the following criteria namely product that is grown naturally, does not damage the environment, is not tested to animals, has degradable or refillable container, is degradable, reusable and biodegradable, has natural ingredients, is made of/from degradable products, is non-toxic or does not contain any chemical beyond the threshold limit of chemicals approved.

Green Consumerism. Green consumerism is indicated by consumer awareness towards their rights to get qualified ans save products so that demand to get environmentalfriendly product is getting stronger. It is series of consumer activities in buying, using and throwing away green products with social responsible value and ethics (Samarasinghe, 2012). Not only does green consumer reflect price and quality, but it also reflect social values and ethics. These increase public awareness and responsibility as well as cause purchase and consumption of environmental-friendly products commonly known as green consumerism (Chan et al, 2008; Bohlen et al, 1993)

Conventional Marketing Mix. Specifically, marketing function can rapidly apply green company strategy through modification of marketing mix such as designing green products, distributing within green criteria, green product price range, green publicity, advertising and sponsor (Rivera-Camino, 2007). However, not every company is ready or willing to apply "green force" to each of their marketing mix tools. Basically, marketing mix was introduced by Borden (1965) consisting of 12 elements namely product design, price, brand, channel of distribution, private sales, advertisement, promotion, packaging, display, service, physical treatment as well as facts and analysis. Furthermore, McCarthy (1964) summarized Borden (1965)'s idea and defined marketing mixture as combination of all of the factors that become responsibility of marketing management to meet the targeted market. McCharty developed 
the four elements of marketing mix known as $4 \mathrm{P}$ that stands for product, price, promotion and place.

Green Consumer Preference. Individual preference is influenced by intrinsic factors that represent individual like and dislike and extrinsic factor such as social condition (Pearce and Robinson, 2008). Consumer preference is defined as individual's opinion towards products s/he consumes, whether s/he likes or does not like them (Kotler, 2009). In line with those ideas, Assael (1998) also defined preference as fondness, choice or ones consumers prefer the most and the consumer preference was developed based one one's perception towards a product.

Previous Studies and Hypothesis. Kumar and Yamuna (2014) conducted a study about the influence of green marketing towards consumer preference in purchasing eco-printers in Sweden. In the study that involved 100 respondents, it was revealed that environmentalfriendly products had significant influence towards consumer preference in buying environmental-friendly products. It supported the findings of the studies conducted by Bhatia and Jain (2013) in India, Getzner and Grabner-Kräuter (2004) in Australia, Millar and Baloglu (2008) in Nevada. Using different object, the study analyzed the implementatiom of green marketing towards consumer preference.

H1: Green marketing has significant influence towards consumer preference.

The finding of Raj et al's study (2013) involving 98 SUV and MUV users in Cochin, Kerala mentioned that the marketing mix consisting of products, price, distribution and promotion had significant influence towards consumer preference in buying cars. Srirram et al (2006)'s study in the USA, Noorali et al (2014)'s in Tehran and Jafari (2016)'s in India also described similar phenomenon. Based on the evidence, the purpose of the study is to analyze the role of conventional marketing mix based on function of the conventional marketing mix towards consumer preference.

H2: Marketing mix has significant influence towards consumer preference.

Based on review of the related literature and the findings of previous study, the hypothesis model of the study is described in Figure 1.

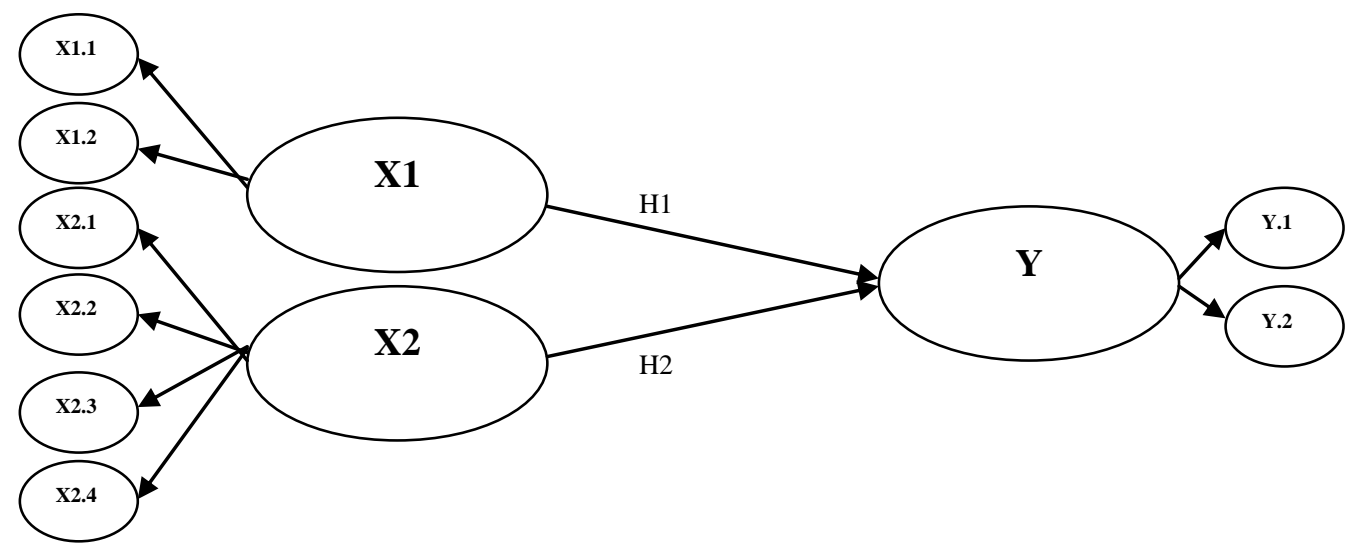

Figure 1 - Hypothesis Model of the Study

Notes:
X1: Green Marketing
X1.1: Green Product
X1.2: Green Consumerism
X2: Marketing Mix
X2.1: Product
$X 2.2$ : Price
X2.3: Channel of Distribution
X2.4: Promotion
Y: Customer Preference
Y1: Weight of Product from Product Attribute
Y2: Product Effect towards the Environment 


\section{METHODOLOGY OF RESEARCH}

Sample and Data Collection. The explanatory study used quantitative research paradigm. The samples were 150 consumers of products manufactured by Nestle in Lampung, Indonesia. I was a one-shot study where the data were gathered simultaneously in one period of time. The data collection was conducted for approximately 4 weeks starting in January 2016 to February 2016.

Furthermore, the study used survey and questionnaire became the instrument. The respondents were identified based on sex, age, occupation, monthly income, and background of education. Path analysis was statistical analysis used for hypothesis testing. It was used to test the hypotheses. Path analysis was used to find out degree of influence in one causal relationship based on the survey. The resuls were presented in development of theoretical model, calculation of coefficient line, path interpretation and direct and indirect hypothesis.

Measuring Variable. The independent variables were green marketing (X1) measured by green product and green consumerism as well as conventional marketing mix (X2) measured by Mccharty (1964)'s Model of Marketing Mix that consisted of product, price, place, promotion. On the other hand, the dependent variable was consumer preference $(\mathrm{Y})$ measured by product attribute and effect of the products towards the environment.

\section{FINDINGS AND DISCUSSIONS}

Result of Path Analysis. Table 1 conveys the results of path analysis. Based on the table, it was found out the partial influence of green marketing by looking at t-ratio $>$ t-table $(5.704<5.731)$ and beta coefficient of 0.564 . These were considered significant and therefore, Green marketing had direct influence towards Consumer preference. Besides that, it was also found out the partial influence conventional marketing mix from t-ratio < t-table $(1.926<5.731)$ and the Beta Coefficient of 0.190 . These were considered insignificant and therefore, conventional marketing mix did not have direct influence towards consumer preference.

Table 1 - Result of Path Analysis

\begin{tabular}{|c|c|c|c|c|c|}
\hline Independent & Dependent & Beta & $\mathrm{T}$ & Sig $\mathrm{t}$ & Description \\
\hline $\mathrm{X} 1$ & \multirow{2}{*}{$\mathrm{Y}$} & 0.564 & 5.704 & 0.000 & Significant \\
\cline { 3 - 6 } & & 0.190 & 1.926 & 0.058 & Insignificant \\
\hline
\end{tabular}

Notes: X1: Green Marketing; X2: Marketing Mix; Y: Customer Preference.

Inter-Variable Relationship. Table 2 described inter-variable relationship measured using coefficient line as the indicator. The coefficient line for inter-variable relationship was conveyed in the coefficient line column based on the path analysis using SPSS. The influence of Green marketing (X1) towards Consumer preference has positive coefficient line of 0.564 . Meanwhile the influence of Conventional marketing mix (X2) towards Consumer preference $(\mathrm{Y})$ had positive coefficient line of 0.190

Table 2 - Inter-Variable Relationship

\begin{tabular}{|c|c|c|c|}
\hline Independent Variable & Dependent Variable & Coefficient Line & Description \\
\hline $\mathrm{X} 1$ & $\mathrm{Y}$ & 0.564 & Significant \\
\hline $\mathrm{X} 2$ & $\mathrm{Y}$ & 0.190 & Insignificant \\
\hline
\end{tabular}

Notes: X1: Green Marketing; X2: Marketing Mix; Y: Customer Preference.

Hypothesis Testing. In order to test whether the independent variables had partial significant influence towards the dependent variable, the $p$-value on significance $\alpha=5 \%$ was used. Table 3 conveyed the results of the hypothesis testing using the $p$-value as indicator, when $\mathrm{p}$-value $<0.05=\mathrm{H} 0$ was rejected and $\mathrm{p}$-value $>0.05=\mathrm{H} 0$ was accepted. 
Table 3 - Hypothesis Testing

\begin{tabular}{|c|c|c|c|c|c|}
\hline Hypothesis & Independent Variables & Dependent Variable & Beta Coefficient & $\mathrm{p}$-value & Description \\
\hline $\mathrm{H} 1$ & $\mathrm{X} 1$ & $\mathrm{Y}$ & 0.564 & 0.000 & Significant \\
\hline $\mathrm{H} 2$ & $\mathrm{X} 2$ & $\mathrm{Y}$ & 0.190 & 0.058 & Insignificant \\
\hline
\end{tabular}

Notes: X1: Green Marketing; X2: Marketing Mix; Y: Customer Preference.

Based on p-value shown in Table 3 , it was found out that the first hypothesis was accepted but the second hypothesis was rejected.

1. Significance of $\mathrm{p}$-value $0.000<0.05=\mathrm{H} 0$ was rejected and $\mathrm{H} 1$ was accepted. It meant green marketing had significant influence towards customer preference. It happened because the consumers began using products that have green/ environmental-friendly concept.

2. Significance of $\mathrm{p}$-value $0.058<0.05=\mathrm{H} 0$ was accepted $\mathrm{H} 2$ was rejected. It meant conventional marketing mix did not have significant influence towards customer preference. It happened because the marketing mix strategy could not influence the consumers through customer preference.

\section{DISCUSSION OF RESULTS}

The results of hypothesis testing showed that the implementation of green marketing could not entirely affect consumer preference. Furthermore, conventional marketing mix did not have significant influence towards consumer preference in buying green products. More detail elaboration is explained in the following sections.

Green Marketing had Significant Influence towards Consumer Preference. The findings showed that green consumption had significant influence towards consumer preference. Their correlation was positive that means better implementation of green marketing would have stronger influence towards consumer preference. The finding also described that green consumerism and green products as the components of green marketing may support high product attribute and effect to the environment weighing as the elements of consumer preference.

The findings is quite surprising for green consumers in developing countries particularly Indonesia. Enviropreneurs try to associate their products as environmental-friendly products with various green products attributes to drive green consumerism. The effort is effective in terms that consumers in Indonesia, as the matter of fact, care about their environment and as the result, they choose types of products they use selectively and make sure they buy environmental-friendly products. It shows an increase in developing countries citizen and consumer's awareness since they opt to make green products their primary options. It means protecting the environment is the first consideration for the customers for their purchase compared to other personal reasons.

These support the findings of Mayank and Amit (2013) in India and Millar and Baloglu (2008)'s study in Nevada that consumer in developing countries has started to develop awareness towards green consumption. The consumers from the developed countries are not the only one purchasing green products as mentioned in the studies conducted by Yamuna (2014) in Sweden and Getzner and Grabner-Kräuter (2004) in Australia.

Conventional Marketing Mix did not have Significant Influence towards Consumer Preference. The findings showed that conventional marketing mix did not have significant influence towards consumer preference. The findings showed that product, price, place and promosi as the elements of conventional marketing mix did not automatically result in high product attribute and effect towards the environment as the indicators of consumer preference.

The findings are contraditory to the findings of the study conducted by Raj et al (2013) in Kerala, Srirram et al (2006) in the USA, Noorali et al (2014) in Teheran and Jafari (2016) in India. It showed that consumers in developing countries more particularly Indonesia paid no attention to whether companies has carried out green product, price, distribution and promotion to encourage preference towards green products. The consumers purchased 
green products solely because of environmental awareness issue and green consumerism behavior they had. They did not consider or analyze further whether one product had met the criteria of green products as a whole or not. They did not think further either product with premium price is decent one or the manufacturers allocated some money for supporting environmental awareness issues. Furthermore, they did not make any attempt to find information about green channel of distribution or whether accurate, informative and trustworthy green promotion had been executed or not.

\section{CONCLUSION}

In line with various issues related to the environment in developing countries more particularly in Indonesia, it seems that the consumers have developed environmental awareness which is predicted to escalate in the future. The public has more information about what happened to the environment and are aware of the impacts the products they use bring to the environment. It means environmental awareness can be transformed into change in personal behavior.

Based on the findings, companies can shape and develop consumer preferences only by intensifying environmental awareness issues in promoting their products. In line with the statement, it is expected that companies that carry out the implementation of green marketing make issues related to the environment not only their minor marketing strategy but also the main focus of their business strategy.

However, in the developing countries it seems that companies are reluctant to carry out the implementation of green marketing as a whole because it may trigger "green wasting" such as high amount of investment in technology or market rejectiondue to higher pricing of green products. Thus many companies only carry out the implementation of green issues in its product without "greening» the overall marketing mix.

Concern raised is that consumers in developing countries may be concerned and care about environmental issues so to improve environmental sustainability, consumers prefer to consume green products. Empathy and in relation to limited information consumers in developing countries about green products and green marketing are allegedly result in the customers lacking understanding about green products since they do not examine further whether the products they consumed are «truly green» or not.

To reduce the investment cost of green technology and the production costs, there is an opportunity for company to have stratagem or business tricks in which the company feels there is no need to carry out comprehensive and complete implementation of green marketing, especially in its marketing mix to influence consumer preference. When no action is taken, more experienced and smarter market will result in consumer sceptism, reduce consumer confidence in buying green products and weaken sustainable competitive advantage.

The study only focuses on high-tech green marketing carried out by MNC in developing country. Further studies may use other implementation of green marketing as the subjects such as start-up business, SMEs or low-tech business. Besides that, future researchers should explore other variables related to green marketing for example, green orientation, green awareness, and green knowledge as well as make relation between these variables and green buying berhaviour.

\section{REFERENCES}

1. Assael, H. (1998). Consumer Behavior And Marketing Action, 6th Edition. Cincinatti, Ohio: South Western College Publishing.

2. Barthel, P., and Ivanaj, V. (2007). Is Sustainable Development In Multinational Enterprises Marketing Issue? Multinational Business Review, 15, No.1, (April 1): 67-82

3. Bhatia, M. and Jain, A. (2013) Green Marketing: A Study On Consumer Perception And Preferences In India. Electronic Green Journal, 1 (36). 
4. Biswas, I. (2016). A Study Of Consumers' Willingness To Pay For Green Products. Journal of Advanced Management Science, Vol. 4, No. 3, pp. 211-215.

5. Bohlen, G.M. et al (1993). Measuring Ecological Concern: A Multi-Construct Perspective. Journal Of Marketing Management, Vol. 10, pp. 415-430

6. Borden, N.H. (1965). The Concept Of The Marketing Mix. In Schwartz, G. (Ed), Science In Marketing. New York: John Wiley \& Sons, 386-397.

7. Boztepe, A. (2012). Green Marketing and Its Impact on Consumer Buying Behavior. European Journal of Economic and Political Studies, 15-21.

8. Brown, M. (1996). Environmental Policy In The Hotel Sector; "Green" Strategy Or Stratagem? International Journal of Contemporary Management, 3(8), P.18-23.

9. Chan, R., Wong, Y., and Leung, T. (2008). Applying Ethical Concepts to the Study of Green Consumers Intentions to Bring Their Own Shopping Bag. Journal of Business Ethics, Vol. 79, Pp.469-481

10. Chhay, L., Mian, M.M. and Suy, R. (2015). Consumer Responses To Green Marketing In Cambodia. Open Journal of Social Sciences, 3, 86-94

11. Das, S.M., Dash, B.M., and Padhy, P.C. (2012). Green Marketing Strategies For Sustainable Business Growth. Journal of Business Management \& Social Sciences Research, Volume 1, No.1, pp.82-87.

12. Dean, T.J., Mcmullen, J.S. (2007). Toward A Theory Of Sustainable Entrepreneurship: Reducing Environmental Degradation Through Entrepreneurial Action. Journal of Business Venturing, 22 (1), 50-76.

13. Follows, S.B and Jobber, D. (2000). Environmentally Responsible Purchase Behavior: A Test Of A Consumer Model. European Journal of Marketing, 34(5/6), 723 -746

14. Fuller D. (1999). Sustainable Marketing: Managerial-Ecological Issues. Sage: 1k Oaks.

15. Getzner, M. et al (2004). Consumer Preferences And Marketing Strategies For "Green Shares». International Journal Of Bank Marketing, 22 (4), 260-278.

16. Gnanapandithan, N. and Rajasekaran, M.R. (n.d.). A Study On Green Marketing: With Special Reference To Organic Product in Coimbatore City. Department Of Commerce, PSG College of Arts and Science, Bharathiar University, Coimbatore.

17. Hassan, Z. and Ali, N.A. (2015). The Impact of Green Marketing Strategy on the Firm's Performance In Malaysia. Procedia - Social and Behavioral Sciences 172, Pp. 463- 470

18. Isaak, R. (1998). Green Logic: Ecopreneurship, Theory And Ethics. Sheffield, UK: Greenleaf Publishing; West Hartford, CT: Kumarian Press.

19. Jarafi, M. (2016). Evaluation Of The Impact Of Services Marketing Mix On Customer Preferences In Selecting A Bank In Khorramabad City. International Business Management, 10 (10): 1851-1860.

20. Kärnä, J., Hansen, E. \& Juslin, H. (2003). Environmental Activity and Forest Certification of Forest Products - A Case Study In Europe. Silva Fennica, 37(2): 253-267

21. Kim, Y. and Choi, S.M. (2005). Antecedents Of Green Purchase Behavior: An Examination Of Collectivism, Environmental Concern, and Pce. Advances in Consumer Research, Volume 32, Association For Consumer Research, Pages: 592-599.

22. Kotler, P. (2009). Manajemen Pemasaran. Jakarta: Erlangga.

23. Kumar, C.D. and Yamuna, S.M. (2014). A Study on Consumer Preference towards Green Marketing Products. Vol. 3, Issue 2, Pp.185-187

24. Lee, K. (2009). Gender Differences in Hong Kong Adolescent Consumers Green Purchasing Behavior. Journal Of Consumer Marketing, 26(2), 87-96.

25. Marques, C. P., and Almeida, D. (2013). A Path Model of Attitudinal Antecedents of Green Purchase Behavior. Economics and Sociology, 6(2), 135-144

26. McCarthy, E.J. (1964). Basic Marketing. II: Richard D. Irwin.

27. McCarty, J.A. et al (2001). The Influence of Individualism, Collectivism, and Locus of Control on Environmental Beliefs and Behavior. Journal Of Public Policy and Marketing, 20, 93-104.

28. Getzner, M. and Grabner-Kräuter, S. (2004). Consumer Preferences and Marketing Strategies for "Green Shares": Specifics of the Austrian Market. International Journal of Bank Marketing, Vol. 22 Iss: 4, pp.260 - 278. 
29. Khoirudin, M. et al (2016). Penerapan Green Marketing Pada Upaya Membentuk Brand Image Dalam Menciptakan Corporate Image Go Green (Studi Pada PT. Cabot Indonesia, Jakarta). Jurnal Administrasi Bisnis (JAB), Vol. 33 No. 1, pp. 69-78.

30. Millar, M. and Baloglu, S. (2008). Hotel Guests Preferences for Green Hotel Attributes. Paper Presented at the 26th Eurochrie, Dubai.

31. Morrone, D., Russo, A, and Calace, D. (2015). The Effectiveness of Green Marketing Strategies in the Automotive Industry: A Consumer-Based Analysis. Journal of Marketing Development and Competitiveness, Vol. 9(2), pp. 59-71.

32. Nestle Indonesia (2013). Creating Shared Value 2013: Turut Menjaga Keberlanjutan Air. Jakarta: Nestle Indonesia

33. Nestle Indonesia (2014). Tiga Pabrik Nestlé Raih Penghargaan Industri Hijau 2014. Retrieved from https://www.Nestle.Co.Id/Ina/Media/Press-Releases/Tiga-Pabrik-NestleRaih-Penghargaan-Industri-Hijau-2014, on January 17, 2016 at 09.15 a.m.

34. Noorali, M.R., Karampour, A.H., and Razmavar, T. (2014). Product Rating Based on Marketing Mix Elements According to Customers' Preference Using ANP Technique (Case Study: Market Of Laptops Asus, Dell, Hp And Sony in Tehran. Journal of Applied Sciences Research, 10 (3), March, pp.176-181.

35. Ogunmokun, G., Tripolitano, A., Rose, J. (2012). An Examination of Firms Environmental Marketing Practices, Sustainability and Business Performance. International Journal of Humanities and Social Science, Vol. 2 No. 3, pp. 49-53.

36. Ottman J. (1992). Greener Marketing. NTC: Lincolnwood, II.

37. Pearce, J.A. and Robinson Jr., R.B. (2008). Manajemen Strategis 10. Jakarta.

38. Peattie, K., and Crane, A. (2005). Green Marketing: Legend, Myth, Farces or Prophesies? Qualitative Market Research: An International Journal, 8(4), 357-370.

39. Pride, W.M. and Ferrell, O.C. (1993). Marketing, 8th Ed. Houghton Mifflin, Boston: MA

40. Raj, M.P.M., Sasikumar, J., and Sriram, S. (2013). A Study of Customers Brand Preference in SUVs and MUVs: Effect on Marketing Mix Variables. International Referred Research Journal, Vol. IV, Issue 1, pp. 48-58.

41. Chan, R.Y.K. and Lau, L.B.Y. (2000). Antecedents Of Green Purchases: A Survey In China. Journal of Consumer Marketing, Vol. 17 Iss: 4, pp.338 - 357.

42. Rivera-Camino, J. (2007). Re-Evaluating Green Marketing Strategy: A Stakeholder Perspective. European Journal of Marketing, 41(11), 1328-1358.

43. Saini, B. (2013). Green Marketing and Its Impact on Consumer Buying Behavior. International Journal Of Engineering Science Invention, Volume 2 Issue 12, pp.61-64.

44. Samarasinghe, D.S.R. (2012). Green Segmentation: Identifying the Green Consumer Demographic Profiles in Sri Lanka. Int. J. of Marketing and Technology, 2(4), 318-331.

45. Siddique, M., Hayat, K., Akbar, I., and Cheema, K.U.R. (2013). Impediments of Green Marketing in Pakistan. International Journal Of Management and Organizational Studies, Volume 2, Issue 1, Page 22-27.

46. Silvia, F. et al (2014). Pengaruh Green Marketing Terhadap Citra Merek Serta Dampaknya Pada Keputusan Pembelian (Survei Pada Konsultan Independen Di Oriflame Cabang Surabaya). Jurnal Administrasi Bisnis (JAB),1(14), pp.1-9.

47. Singh, E.R. and Khan, M.S. (2014). Green Marketing and Its Impact on Society: Emerging Challenges \& Opportunities. International Journal of Management and International Business Studies, Volume 4, Number 3, (2014), pp. 263-270.

48. Tantawi, P., O'shaughnessy, N., Gad, K., and Ragheb, A.S.M. (2009). Green Consciousness of Consumers in a Developing Country: A Study of Egyptian Consumers. Contemporary Management Research, Vol. 5, No. 1., pp. 29-50.

49. Tilikidou, I. (2007). The Effects of Knowledge and Attitudes upon Greeks' ProEnvironmental Purchasing Behavior. Corporate Social Responsibility and Environmental Management, 14: 121-134.

50. Vardarajan, P. (1992). Marketing's Contribution to Strategy: The View from a Different Looking Glass. Journal of the Academy of Marketing Science, 20: 323-343.

51. Yilmazsoy, B., Schmidbauer, H., and Rösch, A. (2015), Green Segmentation: A CrossNational Study. Marketing Intelligence \& Planning, Vol. 33 Iss: 7, pp.981-1003. 